\title{
Ability of Allium cepa L. root tips and Tradescantia pallida var. purpurea in $N$-nitrosodiethylamine genotoxicity and mutagenicity evaluation
}

\author{
ClAUdia R. DE RAINHO, ANDRÉA KAEZER, ClAUdia A.F. AIUB and ISRAEL FElzenSZWALB
}

Departamento de Biofísica e Biometria, Instituto de Biologia Roberto Alcantara Gomes, Universidade do Estado do Rio de Janeiro Av. 28 de setembro, 87 fundos, $4^{\circ}$ andar, Vila Isabel, 20551-030 Rio de Janeiro, RJ, Brasil

Manuscript received on November 3, 2009; accepted for publication on July 14, 2010

\begin{abstract}
$N$-nitroso compounds, such as $N$-nitrosodiethylamine (NDEA), can be formed by the reaction of secundary amines with nitrosating agents, and are suspected to be involved in tumors in humans. NDEA has been considered a weak carcinogen in genotoxic assays probably due to the inefficient nitrosamine activation system that is used and/or to the efficient repair system. In this work, we evaluated the sensibility of Allium cepa L. root tips and Tradescantia stamen hair mutation assay (Trad-SH) using Tradescantia pallida var. purpurea for NDEA $(0.1 ; 0.5 ; 5$ and $25 \mathrm{mM})$ genotoxicity and mutagenicity induction. Allium cepa L. was treated with different NDEA concentrations for $3 \mathrm{~h}$, for 3 consecutive days, including negative control (distilled water) and positive control maleic hydrazide ( $\mathrm{MH} 30 \mu \mathrm{g} / \mathrm{mL})$. After treatment, the roots were hydrolyzed, squashed, and the mitotic index (MI) and cytological abnormalities were scored. The results revealed a cytostatic effect of NDEA $(0.5$ and $5 \mathrm{mM})$, showing a significant reduction in the MI. Chromosome stickiness suggests a NDEA toxic effect. T. pallida purpurea did not respond to mutagens with a dosedependent pattern. In conclusion, our study indicates that the root tips of Allium cepa L. have sensibility to detect NDEA genotoxicity, but not for Trad-SH test.
\end{abstract}

Key words: Allium cepa, genotoxicity, mutagenicity, $N$-nitrosodiethylamine, Tradescantia pallida var. purpurea.

\section{INTRODUCTION}

Studies on the mechanisms of the cancer induction process have revealed that specific chemical compounds are able to produce diseases by themselves (Miller 1970, Aiub et al. 2006). $N$-nitroso compounds, such as $N$ nitrosodiethylamine (NDEA), can be formed by the reaction of secundary amines with nitrosating agents, and are suspected to be involved in tumors in humans ( $\mathrm{Li}-$ jinsky 1992, Aiub et al. 2006). The importance of the analytical determination of the compounds is owing to the carcinogenicity of nitrosamines and their formation. $N$-nitrosamines can be found in treated wastewater effluents, as well as in ground and drinking water (Charrois et al. 2007, Jurado-Sánchez et al. 2009). The domi-

Correspondence to: I. Felzenszwalb

E-mail: uerj.felzen@gmail.com nant formation pathways involved a nitrosation reaction between monochloroamine and dimethylamine tertiary amines, both mutagenics (Mitch and Sedlak 2002, Choi and Valentine 2003, Jurado-Sánchez et al. 2009). NDEA is activated by cytochrome P450 enzymes and preferable results in the ethylation of $N^{7}$ and in the $O^{6}$ position of guanine (Pegg 1983, Aiub et al. 2004) and a lower level of ethylation is also observed at $O^{4}$ position of thymine (Saffhill et al. 1985, Aiub et al. 2004), (Wild and Montesano 1991, Nakatsuru et al. 1993). The precarcinogenic lesions $O^{6}$-ethylguanine and $O^{4}$-ethylthymine, if not repaired, will lead to mutation and tumour formation in superior animals (Pegg 1983, Wild and Montesano 1991, Aiub et al. 2004). Nitrosamines have been considered a weak carcinogen in genotoxic assays (McCann et al. 1975, Maron and Ames 1983, 
Zeiger et al. 1987, Aiub et al. 2004). The reason for these can be due to the authors usually testing NDEA at much higher concentrations than those expected in vivo (Simmon 1979, Aiub et al. 2003). The apparent inconsistency in NDEA results presented in many papers could be attributed mainly to the inefficient nitrosamine activation system used and/or to the efficient repair system (Yahagi et al. 1977, Mohn 1981, Prival and Mitchell 1981, Aiub et al. 2003).

The mutagenicity and genotoxicity evaluation, using more than one test system, is often pointed out. One of the main reasons for using several tests is either to investigate whether different biological models and cell types differ in their sensitivity to environmental chemicals, and to obtain information concerning the predictive value of short-term tests (Fiskesjö 1981). Plant test systems are important to detect mutagens in different environments, since they combine a high sensibility and a great capacity to evaluate distinct genetic endpoints, from point mutations to chromosomal aberrations, either in individual cells or in organs such as leaves, pollens and endosperm (Grant 1994).

The species Allium cepa presents advantages, including low raising costs, easy handling, and suitable chromosomal features. This plant bears large and few chromosomes $(2 \mathrm{n}=16)$, which facilitates the evaluation of chromosome damages and/or disturbances in cell division cycle, including eventual aneuploidy risks (Grant 1982, Fiskesjö 1985, Morais Leme and MarinMorales 2008). Root tips of Allium cepa L. have been recommended as a standard for cytogenetic assay in environmental monitoring due to the correlation of these plants with mammalian and non-mammalian test systems (Constantin and Owen 1982, Cauhan et al. 1999, Nilüfer et al. 2008).

The Tradescantia stamen hair mutation assay (Trad-SH) was developed by Dr. Arnold H. Sparrow and colleagues during the late 1950s and throughout the 1960s at the Brookhaven National Laboratory, Long Island, NY. The Trad-SH is a simple, cost effective short-term bioassay that yields data within 11-14 days, and is easily adapted for either in house or in situ monitoring. The assay is able to detect volatile organic compounds, agents in liquid form, and has a high sensitivity to gaseous mutagens (Ma et al. 1994). The main cells in this assay are the mitotic stamen hair cells developing in the young flower buds. The traditional assay is based on the fact that these stamen hair cells in Tradescantia clone 4430 are heterozygous, being the phenotypic change in pigmentation ranging from blue (dominant) to pink (recessive) among blue cells, which is a single mutant event (Ma et al. 1994). The genotype of Tradescantia pallida var. purpurea concerning the cells that are present in stamen hair is different from the one of Tradescantia clone 4430, although presenting equal clastogenic sensibility for micronuclei induction (Suyama et al. 2002).

Tradescantia pallida var. purpurea is tetraploid, exhibits a notable resistance to parasites and insects, is spread quite easily, and is widely distributed in the streets and gardens of the Brazilian cities (Suyama et al. 2002).

The aim of the present study was to evaluate the sensibility of root tips of Allium cepa L. and Trad-SH assay test using Tradescantia pallida var. purpura, for NDEA genotoxicity and mutagenicity.

\section{MATERIALS AND METHODS}

\section{Chemical Products}

In this study, it was used NDEA (CAS no.: 55-18-5), chemical formula $\mathrm{C}_{4} \mathrm{H}_{10} \mathrm{~N}_{2} \mathrm{O}$, molecular weight 102.1, maleic hydrazide (MH) (CAS no.: 123-33-1), chemical formula $\mathrm{C}_{4} \mathrm{H}_{4} \mathrm{~N}_{2} \mathrm{O}_{2}$, molecular weight 112.09; all of them obtained from Sigma (St. Louis, Mo, USA).

\section{RoOT TIPs OF Allium cepa L.}

Onion bulbus (Allium cepa L., $2 \mathrm{n}=16$ ) were obtained commercially and were placed in small jars with the basal ends dipping in distilled water. The new emerged roots (1-2 $\mathrm{cm}$ in length) were treated with a series of NDEA concentrations $(0.1 ; 0.5 ; 5$ and $25 \mathrm{Mm})$ for $3 \mathrm{~h}$, for 3 consecutive days, and diluted with distilled water. For the negative control it was used distilled water and, for the positive control, MH $30 \mu \mathrm{g} / \mathrm{mL}$. The NDEA treatment and control roots that were exposed were removed from the bulbs and hydrolyzed with a solution composed of 9 parts of $45 \%$ acetic acid and 1 part of $1 \mathrm{~N}$ hydrochloric acid, at $50^{\circ} \mathrm{C}$, for 5-6 min. Later, the hydrolyzed root tips were squashed in slides and stained with $2 \%$ aceto-orcein (Cabrera and Rodriguez 
1999). Three independent assays were performed for each treatment, and scoring was done from the three roots in triplicates. The MI (Mitotic Index) was calculated for each treatment as a number of dividing cells/100 cells. The cytological abnormalities (anaphase bridges, laggards, micronuclei and stickiness) were scored in the mitotic cells. Statistical analysis - one-way analysis of variance (ANOVA) - was used as described elsewhere (Aiub et al. 2004).

\section{Tradescantia Stamen Hair Mutation Assay} (TRAD-SH)

The assessment of in situ mutagenesis involved exposure of Tradescantia pallida var. purpurea in pots containing a 3:1 mixture of sieved soil and vermiculite. The plants were watered three times a week and received $100 \mathrm{~mL}$ of Hoagland nutrient solution, twice per month. The treatment was done with NDEA at concentrations: $0.1 ; 0.5 ; 5$ and $25 \mathrm{mM}$ for 3 consecutive days. As negative control it was used distilled water, and as positive controls $\mathrm{MH}(30 \mu \mathrm{g} / \mathrm{mL})$ and X-ray (100 cGy) by means of a therapeutic X-ray device (Pantak Seifert), operated at $50 \mathrm{kV}, 30 \mathrm{~mA}$. After 7-14 days of treatment, 10 appropriate young inflorescences from each sample were used, and the stamens of the recently opened flowers were cut and placed on a slide. Hairs and mutation events were counted under $40 \mathrm{X}$ magnification. A mutation event consists of one or a sequence of adjacent white cells among the dominant pink cells, in any position of the stamen hair. Statistical analysis - one-way analysis of variance (ANOVA) - was used as described elsewhere (Aiub et al. 2004).

\section{RESULTS}

Root TIPs of Allium cepa L.

The MI and, consequently, the frequency of mitotic phases are given in Table I for cells of Allium cepa treatments with NDEA at concentrations $0.1 \mathrm{mM} ; 0.5 \mathrm{mM}$; $5 \mathrm{mM}$ and $25 \mathrm{mM}$.

The Allium cepa cell roots treated with NDEA $(0.5 \mathrm{mM}$ and $5 \mathrm{mM})$ showed a decrease in the MI $(p<$ $0.05)$ compared with the negative control, which suggests a suggesting genotoxic effect, not dose-dependent. At same concentrations, we observed a reduction in the number of cells in prophase and metaphase, especially for NDEA at $0.5 \mathrm{mM}$, which indicates later in the cell cycle. NDEA treatments induced a wide range of mitotic abnormalities in the root tips of $A$. серa L. The types and percentage of these abnormalities are given in Table II and represented in Figure 1 as anaphase bridges, laggards, micronuclei and stickiness.

We observed a significant increase in the total abnormalities for all NDEA concentrations compared with the negative control $(p<0.05)$. Anaphase bridges $(8 \%)$ were verified only at NDEA $0.5 \mathrm{mM}$, although, for all concentrations, lagging chromosome was observed. We detected the occurrence of micronuclei for all NDEA concentrations, especially at 0.5 and $5 \mathrm{mM}$, increasing $25 \%$ and $30 \%$, respectively ( $p<0.05$ ). Chromosome stickiness $(37 \%)$ increases for all NDEA concentrations $(p<0.05$ at $25 \mathrm{mM})$.

Tradescantia StAmen HAIR MUtATION ASSAY (TRAD-SH)

Mutation frequencies were obtained in Tradescantia pallida var. purpurea exposed to NDEA at different concentrations (Table III).

We do not observe a significant result even when compared with negative and positive controls.

\section{DISCUSSION}

The root tips of Allium cepa L. have often been used for the determination of cytotoxic (Vicentin et al. 2001), cytostatic and/or genotoxic effects of some substances (Nilüfer et al. 2008). Moreover, for in situ monitoring, meristematic cells of Allium cepa L. were a very efficient cytogenetic material for detection of mutagenic activity of the environmental chemicals helping in cancer research (Levan 1951, Ma et al. 1995, Ateeq et al. 2002, Nilüfer et al. 2008). NDEA is activated by cytochrome P450 enzymes (Pegg 1983, Aiub et al. 2004). These enzymes play an important role in the detoxification process in higher plants as well (Werck et al. 1990, Sandermann 1992, Riffat and Masood 2006). Many studies have shown an interest in the mechanism of cytochrome P450 dependent mixed function oxidases with particular reference to ethoxy resorufin O-deethylase (EROD) activity, as a response of the organism to the presence of pollutants in the aquatic environment (Payne 
TABLE I

Mitotic index and the percentage of mitosis stages in the root tip cells of $A$. cepa treated with different NDEA concentrations.

\begin{tabular}{c|c|c|c|c|c}
\hline $\begin{array}{c}\text { Concentration } \\
(\mathrm{mM})\end{array}$ & $\begin{array}{c}\text { Mitotic } \\
\text { index }\end{array}$ & $\begin{array}{c}\% \\
\text { Prophase }\end{array}$ & $\begin{array}{c}\% \\
\text { Metaphase }\end{array}$ & $\begin{array}{c}\% \\
\text { Anaphase }\end{array}$ & $\begin{array}{c}\% \\
\text { Telophase }\end{array}$ \\
\hline Negative Control & $9.88 \pm 0.25$ & 50 & 30 & 10 & 10 \\
\hline $0.1 \mathrm{mM}$ & $8.04 \pm 0.01$ & 30 & 30 & 20 & 20 \\
\hline $0.5 \mathrm{mM}$ & $1.13 \pm 0.98^{*}$ & $18^{*}$ & $10^{*}$ & 36 & 36 \\
\hline $5 \mathrm{mM}$ & $1.70 \pm 0.26^{*}$ & $15^{*}$ & 55 & 15 & 15 \\
\hline $25 \mathrm{mM}$ & $5.23 \pm 2 *$ & $18^{*}$ & 36 & 5 & 41 \\
\hline Positive Control & $0.34 \pm 0.76$ & 100 & 0 & 0 & 0 \\
\hline
\end{tabular}

Negative Control: distilled water. Positive Control: MH $30 \mu \mathrm{g} / \mathrm{mL}$. Statistical analysis related to negative control $* p<0.05$.

TABLE II

Mitotic aberrations in the root tip cells of $A$. cepa treated different NDEA concentrations.

\begin{tabular}{c|c|c|c|c|c}
\hline $\begin{array}{c}\text { Concentration } \\
(\mathrm{mM})\end{array}$ & $\begin{array}{c}\% \text { Total } \\
\text { abnormalities }\end{array}$ & $\begin{array}{c}\% \\
\text { A.B. }\end{array}$ & $\begin{array}{c}\% \\
\text { L. }\end{array}$ & $\begin{array}{c}\% \\
\text { MN. }\end{array}$ & $\begin{array}{c}\% \\
\text { S. }\end{array}$ \\
\hline Negative Control & 0 & 0 & 0 & 0 & 0 \\
\hline $0.1 \mathrm{mM}$ & $59^{*}$ & 0 & 23 & 6 & $30^{*}$ \\
\hline $0.5 \mathrm{mM}$ & $74^{*}$ & 8 & 16 & $25^{*}$ & $25^{*}$ \\
\hline $5 \mathrm{mM}$ & $75^{*}$ & 0 & 15 & $30^{*}$ & $30^{*}$ \\
\hline $25 \mathrm{mM}$ & $79^{*}$ & 0 & 23 & 19 & $37^{*}$ \\
\hline Positive Control & 100 & 0 & 0 & 100 & 0 \\
\hline
\end{tabular}

A.B., anaphase bridges; L., laggards; MN., micronucleus; S., stickiness. Negative Control: distilled water. Positive Control: MH $30 \mu \mathrm{g} / \mathrm{mL}$. Statistical analysis related to negative control $* p<0.05$.

et al. 1987, Aas et al. 2001, Bard et al. 2002, Moore et al. 2003, Riffat and Masood 2006).

Our findings reflect the utility of root meristem cells of Allium cepa L. for monitoring the genotoxic effects of NDEA as reported to other nitroso compound (Fiskesjö 1981). We demonstrated NDEA cytostatic effect $(0.5$ and $5 \mathrm{mM}$ ) through a significant reduction in the mitotic index (MI) in a dose dependent manner (Table I). The delay observed in mitosis (Table I) could be due to the inhibition of DNA synthesis (Schneiderman et al. 1971, Sudhakar et al. 2001, Türkǒglu 2007) or to a blocking in the G2-phase of the cell cycle, preventing mitosis (Van't Hof 1968, Türkǒglu 2007).

Significantly higher frequencies of mitotic aberrations indicate the primary action of $\operatorname{NDEA}(0.5 \mathrm{mM})$ on mitotic spindles, which leads to the induction of sev- eral spindle-related abnormalities like laggarding chromosomes, stickiness and micronuclei. Our results show that NDEA treatment for all concentrations presents a significant higher mitotic aberrations compared with the control group ( $p<0.05)$, and chromosome stickiness was the main alteration (Table II). NDEA induced a significant increase of chromosome stickiness in all concentrations, which indicates high toxic effect. Other nitroso compounds like N-Methyl- $N^{\prime}$-Nitro-N-Nitrosoguanidine (MNNG) and 4,6-Dinitro-O-Cresol also showed stickiness effect using the same method (Fiskesjö 1981, Nilüfer et al. 2008).

NDEA at 0.5 and $5 \mathrm{mM}$ showed a significant increase in micronucleus, which suggests acentric fragments or lagging chromosomes that fail to incorporate into either of daughter nuclei during the telophase of the 

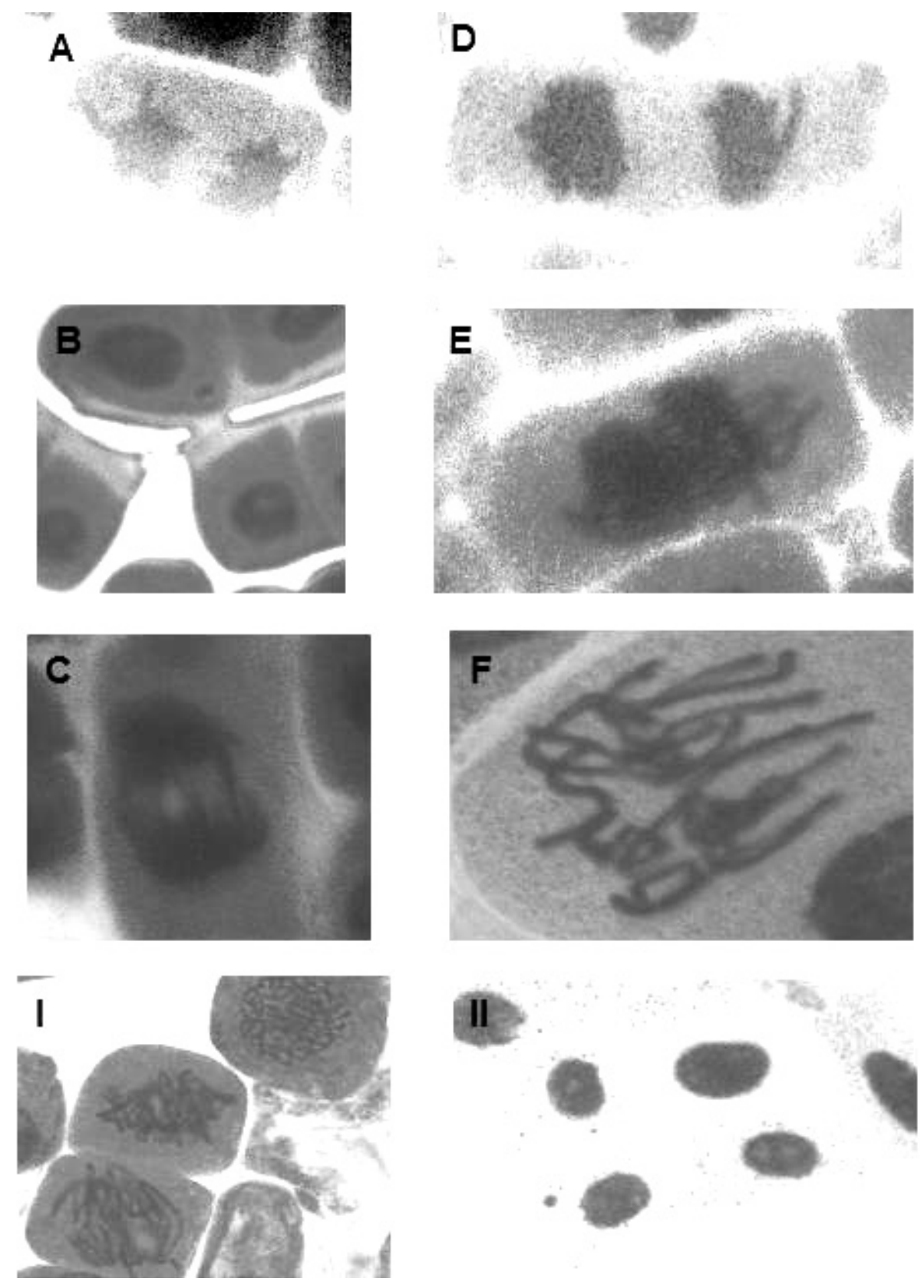

Fig. 1 - Different types of aberration induced by NDEA in Allium cepa root tips: (A) lagging chromosome at anaphase (25mM); (B) micronucleus at interphase $(5 \mathrm{mM})$; (C) bridge formation $(0.5 \mathrm{mM})$; (D) lagging chromosome at anaphase $(0.5 \mathrm{mM})$; (E) stickiness formation $(0.1 \mathrm{mM})$; (F) chromosome break at metaphase $(0.1 \mathrm{mM})$. (I) normals prophase, metaphase and anaphase induced by negative control (water); (II) micronucleus and high synthesis of protein induced by positive control (MH $30 \mu \mathrm{g} / \mathrm{mL})$.

mitotic cells. Besides, micronucleus formation implies in loss of genetic material and DNA breakage, which leads to a clastogenic effect (Sudhakar et al. 2001, Türkǒglu 2007). The bridges noticed in the cells are probably formed by breakage and fusion of chromosomes and chromatids (Türkǒglu 2007). Besides, lagging chromosome was due to the failure of the chromosomes to move to either of poles or acentric chromosome fragment (Türkǒglu 2007). In addition to the above-mentioned type of abnormalities, stickiness, chromosome breaks 
TABLE III

Frequency of mutation (mutations/100) in stamen hairs of Tradescantia pallida var. purpurea treated with different NDEA concentrations.

\begin{tabular}{c|c}
\hline $\begin{array}{c}\text { Concentration } \\
(\mathrm{mM})\end{array}$ & $\begin{array}{c}\text { SH frequency } \\
(\text { Mean } \pm \text { S.D. })\end{array}$ \\
\hline Negative Control & $1.4 \pm 0.005$ \\
\hline 0.1 & $0.84 \pm 0.19$ \\
\hline 0.5 & $1 \pm 0.01$ \\
\hline 5 & $0.79 \pm 0.37$ \\
\hline 25 & $1.04 \pm 0.01$ \\
\hline $\mathrm{MH}_{\mathrm{a}}$ & $1.03 \pm 0.6$ \\
\hline $100 \mathrm{cGY}_{\mathrm{aa}}$ & $1.01 \pm 0.01$ \\
\hline
\end{tabular}

Negative Control: distilled water. a Positive Control: MH $30 \mu \mathrm{g} / \mathrm{mL}$; aaPositive Control: X-ray $100 \mathrm{cGY}$. $* p<0.05$.

and unequal chromosome distribution were observed for all NDEA concentrations, but no significant increase was observed compared with the negative control.

Our results in root tips of Allium cepa L. test are in agreement with NDEA genotoxicity and mutagenicity using SOS chromotest and Ames test, respectively. We verified, using SOS chromotest, an induction of sfiA expression in the uvrA Escherichia coli tester strains (PQ35, PQ37 PQ65 and PQ66) that occurred at doses between it 0.75 and $36.46 \mu \mathrm{g} / \mathrm{ml}$, with $\mathrm{S} 9$ mix and in PQ66, without the S9 mix, for $36.46 \mu \mathrm{g} / \mathrm{ml}$ of NDEA concentration. In Ames test, was detected a mutagenic response in Salmonella typhimurium strains TA98 (NDEA $25.47 \mu \mathrm{g}$ per plate) and TA100 (NDEA $5.09 \mu \mathrm{g}$ per plate) in the presence of the S9 mix with preincubation of 90 min (Aiub et al. 2003). As the NDEA concentrations used in S. typhimurium Ames test $(\mu \mathrm{g} /$ $\mathrm{mL}$ ) are much lower than others used for Allium cepa assay $(\mathrm{mM})$, we suggest that high concentrations can induce chromosomal aberrations including DNA breaks, as demonstrated for MN. Other possibility is the ability of superior plants to possess the integrity of cytochrome P450, which increases the generated metabolites.

One of the methods most widely used to detect genotoxic activity of chemical or physical agents is the somatic mutation test on Tradescantia staminal hairs (clone 4430). This test is based on the fact that Tradescantia staminal hairs cells are heterozygous for color
(Aa). The dominant allele (A) accounts for the blue color, and the recessive allele (a) is responsible for the pink color. Mutation in the dominant allele will result in the expression of the recessive allele (pink cells) (Ma et al. 1994), (Moya-Alvarez et al. 2001). We supposed that Tradescantia pallida var. purpurea has recessive white cells and domination pink cells. This characteristic is different in the clone 4430, which has pink cells recessive and domination blue cells (Ma et al. 1994). The choice of Tradescantia pallida var. purpurea test was based on two criteria generally taken into consideration in biomonitoring: its wide distribution in Rio de Janeiro and its easy propagation. As the first step in our study, we decided to test the sensitivity of T. pallida purpurea to known mutagens, like NDEA, and to test its capacity to respond in terms of mutagenic events (characterized by color change) formed in stamen hair. The results depicted in Table III clearly indicate that $T$. pallida purpurea did not respond to NDEA induced DNA damage with a dosedependent pattern. These results are similar to the ones of other works that have been reported with Tradescantia staminal hairs (clone 4430) using 1, 5 and $10 \mathrm{mM}$ (Moya-Alvarez et al. 2001).

In conclusion, our study indicated that the root tips of Allium cepa L. have sensibility to detect NDEA genotoxicity. However, Trad-SH test using T. pallida purpurea is not sensitive to detect NDEA mutagenicity.

\section{ACKNOWLEDGMENTS}

This work was supported by Fundação Carlos Chagas Filho de Amparo à Pesquisa do Estado do Rio de Janeiro (FAPERJ), Conselho Nacional de Desenvolvimento Científico e Tecnológico (CNPq), Coordenação de Aperfeiçoamento de Pessoal de Nível Superior (CAPES) and Sub-Reitoria de Pesquisa da Universidade do Estado do Rio de Janeiro (SR2-UERJ).

\section{RESUMO}

Nitrocompostos, como $N$-nitrosodietilamina (NDEA), podem ser formados pela reação entre uma amina secundária e agentes nitrosantes e são suspeitos de estarem envolvidos na formação de tumores em humanos. NDEA é considerada um carcinógeno fraco em ensaios genotóxicos provavelmente pela utilização de um sistema de ativação ineficiente e/ou pela utilização de um eficiente sistema de reparo. Neste trabalho, nós 
avaliamos a sensibilidade de ensaios com Allium cepa L. e Tradescantia pallida var. purpurea (Trad-SH) à genotoxicidade e mutagenicidade induzidas por diferentes concentrações de NDEA $(0,1 ; 0,5 ; 5$ e $25 \mathrm{mM})$ por $3 \mathrm{~h}$, por 3 dias consecutivos, incluindo controle negativo (água destilada) e controle positivo, hidrazida maleica (MH $30 \mu \mathrm{g} / \mathrm{mL}$ ). Depois do tratamento, as raízes foram hidrolizadas, esmagadas e o índice mitótico (IM) e anormalidades citológicas foram contadas. Os resultados revelaram um efeito citostático de NDEA $(0,5 \mathrm{e}$ $5 \mathrm{mM}$ ), pela significante redução do IM. Chromosome stickiness sugere um efeito citotóxico de NDEA. T. pallida purpurea não respondeu ao mutágeno com um padrão dose dependente. Em conclusão, nossos estudos indicaram que raízes de Allium cepa L. possuem sensibilidade na detecção genotóxica de NDEA, mas não para o ensaio Trad-SH.

Palavras-chave: Allium cepa, genotoxicidade, mutagenicidade, $N$-nitrosodietilamina, Tradescantia pallida var. purpurea.

\section{REFERENCES}

Aas E, Beyer J, Jonsson G, Riechert WL And AnDERSEN OK. 2001. Evidence of uptake, biotransformation and DNA binding of polyaromatic hydrocarbons in Atlantic cod and Corkwing wrase caught in the vicinity of aluminium works. Mar Environ Res 52: 213-229.

Aiub CAF, Ribeiro LF And FelzenszWALb I. 2003. $N$ Nitrosodiethylamine mutagenicity at low concentrations. Tox Lett 145: 36-45.

Aiub CAF, MAZzEI JL, Ribeiro LF AND FELZENSZWALB I. 2004. Participation of BER and NER pathways in the repair of DNA lesions induced at low $N$-nitrosodiethylamine concentrations. Tox Lett 154: 133-142.

Aiub CAF, MAZZEi JL, Ribeiro LF AND FELZENSZWALB I. 2006. Evaluation of nitroreductase and acetyltransferase participation in $N$-nitrosodiethylamine genotoxicity. Chem Biol Interact 161: 146-154.

Ateeq B, Abul FM, Niamat AM and Ahmad W. 2002. Clastogenicity of pentachlorophenol, 2,4-D and butachlor evaluated by Allium root tip test. Mutat Res 514: 105-113.

BARd SM, Woodin BR And Stegeman JJ. 2002. Expression of P-glycoprotein and cytochrome P450 1A in intertidal fish exposed environmental contaminants (Anoplarchus purpurescens. Aquat Toxicol 60: 17-32.

CABRERA GL AND Rodriguez DMG. 1999. Genotoxicity of leachates from a landfill using three bioassays. Mutat Res 426: 207-210.
Cauhan LKS, Saxena PN And Gupta SK. 1999. Cytogenetic effects of cypermetrin and fenvalerate on the root meristem cells of Allium cepa. Environ Exp Bot 42: 181189.

Charrois JWA, Boyd JM, Froese KF ANd Hrudey SE. 2007. Occurrence of $N$-nitrosamines in Alberta public drinking water distribution systems. J Environ Eng Sci 6: 103-114.

Choi J And VAlentine RL. 2003. N-nitrosodimethylamine formation by free-chlorineenhanced nitrosation of dimethylamine. Environ Sci Technol 37: 4871-4876.

CONSTANTIN MJ AND OWEN ET. 1982. Introduction and perspectives of plant genetic and cytogenetic assay, A report of US EPA Gene-Tox programme. Mutat Res 99: $1-12$.

FISKESJÖ G. 1981. Benzo(a)pyrene and $N$-methyl- $N$-nitro$N$-nitrosoguanidine in the Allium test. Hereditas 95: 155162.

FISKESJÖ G. 1985. The Allium test as a standard in environmental monitoring. Hereditas 102: 99-112.

GRANT WF. 1982. Chromosome aberration assays in Allium. A report of the U.S. Environmental Protection Agency Genotox Program. Mutat Res 99: 273-291.

GRANT WF. 1994. The present status of higher plant biossays for the detection of environmental mutagens. Mutat Res 310: 175-185.

JuRAdo-SÁnchez B, BAllestros E And Gallego M. 2009. Fullerenes for aromatic and non-aromatic $N$-nitrosamines discrimination. J Chromat A 1216: 1200-1205.

LEVAN A. 1951. Chemically induced chromosome reactions in Allium cepa and Vicia faba Cold Spring Symp. Quant Biol 16: 233-243.

LIJINSKY W. 1992. Chemistry and Biology of $N$-Nitroso compounds, Cambridge University Press. Cambridge, New York, USA, 463 p.

ma th, Cabrera GL, Cebulska-Wasilewska A, Chen R, Loarca F, Vandenberg AL and SalaMONE MF. 1994. Tradescantia stamen hair mutation bioassay. Mutat Res 310: 211-220.

Ma TH, Xu Z, Xu C, Mc Connell H, Rabago EV, Arreola GA AND Zhang H. 1995. The improved Allium/Vicia root tip micronucleus assay for clastogenicity of environmental pollutants. Mutat Res 334: 185-195.

MARon DM AND AMEs BN. 1983. Revised methods for the Salmonella mutagenicity test. Mutat Res 113: 173215.

McCann J, Choi E, Yamasaki E And Ames BN. 1975. Detection of carcinogenics as mutagens in the Salmonella/microsome test: assay of 300 chemicals. Proc Natl Acad Sci USA 72: 5135-5139. 
Miller JA. 1970. Carcinogenesis by chemicals: an overview. Cancer Res 3: 559-576.

Mitch WA AND SEDLAK DL. 2002. Formation of $N$-nitrosodimethylamine (NDMA) from dimethylamine during chlorination. Environ Sci Technol 36: 588-595.

MOHN GR. 1981. Bacterial systems for carcinogenicity testing. Mutat Res 87: 191-210.

Moore MJ, Mitrofanov IV, Valentine SS, Volkov VV, Kurbskyi AV, Zhimbey EN, EgLinton LB AND Stegeman JJ. 2003. Cytochrome P 450 1A expression, chemical contaminants and histopathology in roach, goby and sturgeon and chemical contaminants in sediments from the Caspian sea, lake Balkash and the Ily river delta, Kazakhstan. Mar Poll Bull 46: 107-119.

Morais Leme D AND MARIN-Morales MA. 2008. Chromosome aberration and micronucleus frequencies in $\mathrm{Al}$ lium cepa cells exposed to petroleum polluted water - A case study. Mutat Res 650: 80-86.

Moya-Alvarez C, Lucas-Santerre A, GonzÁlezZÚNiga G, BugaríntorRes O, CAMBERos-PAdiLHA E AND Velasco AF. 2001. Evaluation of genotoxic activity of maleic hydrazide, ethyl methane sulfonate, and $N$-nitrosodiethylamine in Tradescantia. Salud Pública de México 43: 563-569.

Nakatsuru Y, Matsukuma S, Nemoto N, Sugano H, SEKIGUCHI M AND IsHikAWA T. 1993. $O^{6}$-Methyltransferase protects against nitrosamine-induced hepatocarcinogenesis. Proc Natl Acad Sci USA 90: 6468-6472.

Nilüfer A, Serap C, SEnAy S, Dilek Y AND ÖZElm Ö. 2008. Evaluation of clastogenicity of 4,6-Dinitro-ocresol (DNOC) in Allium root tip test. J Biol Environ SCL 2: 59-63.

PAyne JF, FAncey LL, Rahimtula AD AND Porter EL. 1987. Review and perspective on the use of mixedfunction oxygenase enzymes in biological monitoring. Comp Biochem Physiol 86: 233-245.

PEGG AE. 1983. Alkylating and subsequent repair of DNA after exposure to dimethylnitrosamine and related carcinogenens. Rev Biochem Toxicol 5: 88-123.

PRIVAL MJ AND MitChELL VD. 1981. Influence of microsomal and cytosolic fractions from rat, mouse, and hamster liver on the mutagenicity of dimethylnitrosamine in the Salmonella plate incorporations assay. Cancer Res 41: 4361-4367.

RifFAT AF AND MAsood A. 2006. Allium cepa derived EROD as a potencial biomarker for the presence of certain pesticides in water. Chem 62: 527-537.
SAFFHILl R, MARGISON GP AND O'CONNOR PJ. 1985. Mechanisms of carcinogenesis induced by alkylating agents. Biochim Biophys Acta 823: 111-145.

SANDERmanN H. 1992. Plant metabolism of xenobiotics. Trens Biochem Sci 17: 82-84.

SChNeIderman MH, Dewey WC AND Highfield DP. 1971. Inhibition of DNA synthesis in synchronized Chinese hamster cell treated in G1 with cyclohexamide. Exp Cell Res 67: 147-155.

SIMMON VJ. 1979. In vitro mutagenicity assays of chemical carcinogens and related compounds with Salmonella typhimurium. J Natl Cancer Inst 62: 893-899.

SudhaKar R, Gowda N AND Venu G. 2001. Mitotic abnormalities induced by silk dyeing industry effluents in the cells of Allium cepa. Cytologia 66: 235-239.

Suyama F, Guimaraes ET, Lobo DJA, Rodrigues GS, Domingos M, Alves ES, Carvalho HA And SALDIVA PHN. 2002. Pollen mother cells of Tradescantia clone 4430 and Tradescantia pallida var. purpurea are equally sensitive to the clastogenic effects of Xrays. Braz J Med Biol Res 35: 127-129.

TÜRKǑGLU S. 2007. Genotoxicity of five food preservatives tested on root tips of Allium cepa L. Mutat Res 626: 4-14.

VAN'T HOF J. 1968. The action of IAA and kinetin on the mitotic cycle of proliferative and stationary phase excised root meristem. Exp Cell Res 51: 167-176.

Vicentin VEP, CAMPARoto ML, TeIXeIRA RO AND Mantovani MS. 2001. Averrhoa carabola L., Syzgium cumini (L.) Skeels and Cissus sicyoides L.: medicinal herbal tea effects on vegetal and animal test systems. Acta Scientiarum 23: 593-598.

Werck RD, Gabriac B, Teutsch H ANd Durst F. 1990. Two cytochrome P450 isoforms catalyzing O-deethylation of ethoxycoumarin and ethoxyresorufin in higher plants. Biochem J 270: 729-735.

Wild CP AND Montesano R. 1991. Detection of alkylated DNA adducts in human tissues. In: GROOPMAN JD AND SKIPPER PL (Eds), Molecular Dosimetry \& Human Cancer: Analytical, Epidemiological and social Considerations, CRC Press, Boston, p. 263-279.

Yahagi T, Nagao M, Seino Y, Matsushima T, SugiMURA T AND OKADA M. 1977. Mutagenicities of $N$ nitrosamines on Salmonella. Mutat Res 48: 121-130.

Zeiger E, ANderson B, Harworth S, LAwlor T, Mortelmans K AND SPECK W. 1987. Salmonella mutagenicity tests, III. Results from the testing of 255 chemicals. Environ Mutagen 9: 9-109. 